Article

\title{
Improvement Effect of Reticular Glass Fibers on the Mechanical Properties of Tailings Sand with the Lenticle (Layered Sandy Soil)
}

\author{
Xiaofei Jing ${ }^{1}$, Changshu Pan ${ }^{2, *}$, Yulong Chen ${ }^{3, *}$, Xiangfu $\mathrm{Li}^{4}$, Wensong Wang ${ }^{5}{ }^{\oplus}$ and $\mathrm{Xu} \mathrm{Hu}{ }^{2}$ \\ 1 School of Safety Engineering, Chongqing University of Science and Technology, Chongqing 401331, China; \\ xfjing@cqust.edu.cn \\ 2 Chongqing GaoXin Engineering Survey and Design Institute Ltd., Co., Chongqing 401121, China; \\ huxu_12315@163.com \\ 3 School of Energy and Mining Engineering, China University of Mining and Technology, Beijing 100083, China \\ 4 The Chongqing Engineering Company of Ctce Group, Chongqing 401147, China; m18996325451@163.com \\ 5 College of Resources and Environmental Science, Chongqing University, Chongqing 400044, China; \\ sdgxwws@163.com \\ * Correspondence: pcsqs1@163.com (C.P.); chenyulong@cumtb.edu.cn (Y.C.)
}

check for updates

Citation: Jing, X.; Pan, C.; Chen, Y.; Li, X.; Wang, W.; Hu, X. Improvement Effect of Reticular Glass Fibers on the Mechanical Properties of Tailings Sand with the Lenticle (Layered Sandy Soil). Water 2021, 13, 1379. https://doi.org/10.3390/w13101379

Academic Editor: Athanasios Loukas

Received: 17 April 2021

Accepted: 13 May 2021

Published: 15 May 2021

Publisher's Note: MDPI stays neutral with regard to jurisdictional claims in published maps and institutional affiliations.

Copyright: (c) 2021 by the authors. Licensee MDPI, Basel, Switzerland. This article is an open access article distributed under the terms and conditions of the Creative Commons Attribution (CC BY) license (https:/ / creativecommons.org/licenses/by/ $4.0 /)$.

\begin{abstract}
Glass fiber is a kind of polymer, which can effectively improve the mechanical properties of sand. However, the improvement effect of glass fibers with a reticular structure is different from that of ordinary fibers. At the same time, the sandy soil structure is diversified and part of the soil is layered, such as the lenticle in tailings dam, which often forms layered sandy soil with nearby tailings sand. The existence of the lenticle has adverse effects on the stability of the tailings dam. In order to study the reinforcement effects of reticular glass fibers on tailing sand with the lenticle (layered sand), a series of triaxial shear tests were carried out on the tailings sand by changing the layers of reticular glass fibers and the position of reinforcement. The results demonstrated the following five main points: (1) the shear strength of the tailings with the lenticle is significantly lower than the shear strength of the tailings fine sand, and the influence of the lenticle on the shear strength of the tailings is mainly concentrated on the cohesion. (2) When the reticular fiber is added to the tailings with the lenticle, the cohesion of the sample increases nonlinearly with the increase of the number of fiber layers, while the internal friction angle is basically unchanged. (3) The improvement effect of the reticular fiber on the shear strength of the sample varies with the position of the reinforcement, which is represented as the interface > tailings fine sand > lenticle. (4) Only when the axial strain develops to a certain extent, the reinforcement of the reticular fibers is reflected. (5) The reinforcement effects of reticulated fibers are determined by the interaction of forces at the interface between fibers and sand. The research results can not only provide a scientific basis for the construction of reinforced tailings dam, but also play a guiding role in disaster prevention and mitigation work of reinforced slopes with a weak zone, and even provide the reference for the reinforcement research of layered structures.
\end{abstract}

Keywords: polymers; reticular glass fibers; lenticle; tailings sand; mechanical properties; layered structure

\section{Introduction}

Natural sand has low cohesion and a loose structure, which can easily cause various geological disasters and endanger the stability of roadbeds, slopes and dam bodies. Therefore, sand reinforcement has always been the focus of geotechnical engineering. In recent years, fiber has been more and more popular in geotechnical engineering because of its strong tensile strength being applied in sand and other soil reinforcements [1-5]. Due to the hydrolysis of natural fibers being very common, it reduces their strength and affects the reinforcing effect. Therefore, the common fibers in the field of engineering are artificial fibers, such as glass fibers [6,7]. Research shows that the mechanical properties of glass 
fibers are greater than those of other artificial fibers [8]. If the glass fiber is woven into a mesh structure to form reticular glass fibers, the reinforcement effect will be different from that of filamentous glass fibers. The reticular glass fiber is a new alkali-resistant product, which is made of medium alkali or alkali-free glass fibers and acrylic acid copolymer, woven into the mesh structure. The reticular glass fiber is a kind of composite material of polymer and glass fibers, which has strong corrosion resistance and tensile resistance.

At present, there are more than 12,000 tailings ponds in China, of which $95 \%$ are constructed by the upstream method [9]. Under ideal conditions, due to the difference in carrying capacity, during the discharge process, the tailings sand successively deposits coarse sand, medium sand and fine sand according to the particle size, as shown in Figure 1a. However, in the process of upstream dam construction, the slurry is often affected by many factors, such as slurry concentration, tailings size, flow rate and discharge mode. Thus, the tailings dam often produces some interlayers with poor permeability [10]. These interlayers are called lenticle [11], as shown in Figure 1b. The existence of the lenticle reflects the normal deposition state of the tailings during upstream dam construction, and its distribution also seriously affects the stability of the dam [12]. Generally, when the lenticle is distributed at the dam crest, the stability of the dam is the best, the bottom is the second, and the middle is the worst. Studies have shown that the lenticle can seriously affect the stability of the sand-soil system, especially in the tailings dam [13,14]. The reason is that there are large differences in mechanical properties between the lenticle and the nearby tailings sand, which block the continuity of tailings during the discharge process. Additionally, the lenticles are fine particles, and fine particles have smaller permeability than coarse particles [15-18].

For this reason, the researchers have carried out some research on the lenticle in the tailings dam through mechanical experiments and numerical simulations, and found that the impact of the lenticle on the tailings dam is mainly reflected in the following two aspects [19]: (1) the influence of the geometric parameters (vertical distribution, horizontal distribution, area ratio, shape and size) of the lenticle on the tailings dam is mainly reflected in the displacement of the dam crest. In general, the larger the area ratio of the lenticle, the shallower the depth of the infiltration line, the greater the displacement of the dam crest and the worse the safety of the dam [20]. (2) The influence of the material parameters (permeability coefficient, stiffness parameter, poisson's ratio and strength parameter) of the lenticle on the tailings dam is mainly reflected in the safety factor of the dam. Generally, the larger the permeability coefficient and the higher the shear strength, the greater the safety factor of the dam [21].

In summary, the lenticle has a serious impact on the stability of the tailings dam, so measures must be taken to reinforce the tailings dam with the lenticle. Professor Wei used the geosynthetic material [22] as the reinforced material to strengthen the tailings dam with a lenticle by using the reinforced terraced method (RTFM) [23]. It was found that this method can improve the stability of the dam by $10 \%-20 \%$. However, this study only studied the overall stability of the dam, and did not conduct in-depth research on the strength characteristics of the reinforced composite.

The distribution of the lenticle in the tailings dam is uneven, as shown in Figure 1c. Layered sandy soil will be formed between lenticle and adjacent tailings sand, and the mechanical properties of layered sandy soil are quite different from those of single-layer soil. In order to understand the mechanical properties of reinforced layered sandy soil, the reticular fibers are used as the reinforced material [24-26], and the reinforced density and the reinforced position are used as dependent variables. A series of mechanical tests were carried out on reinforced tailings with the lenticle. The research results can not only provide theoretical support for the construction of tailings dam, but also provide a reference for the reinforced engineering of layered soil. 


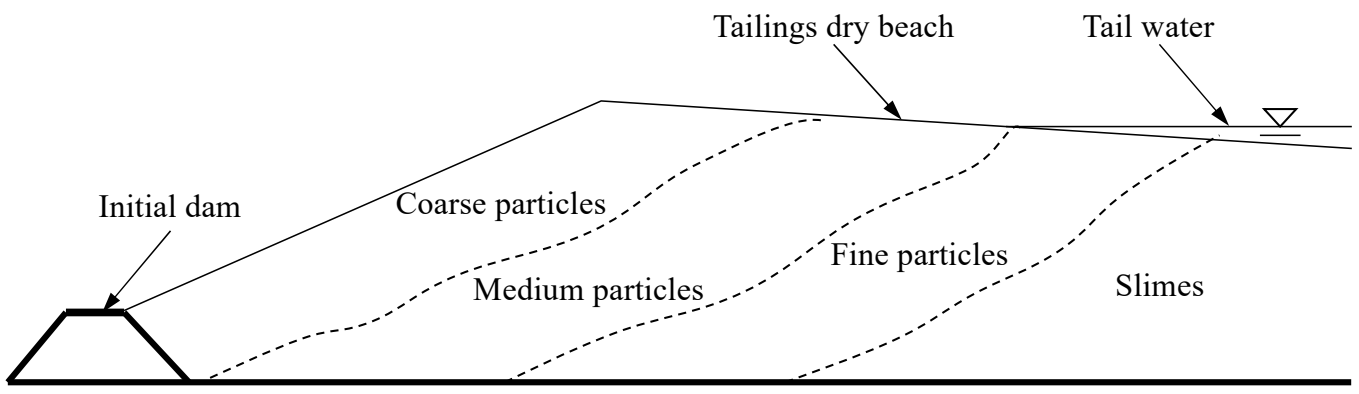

(a) Ideal cross-sectional of tailings dam.

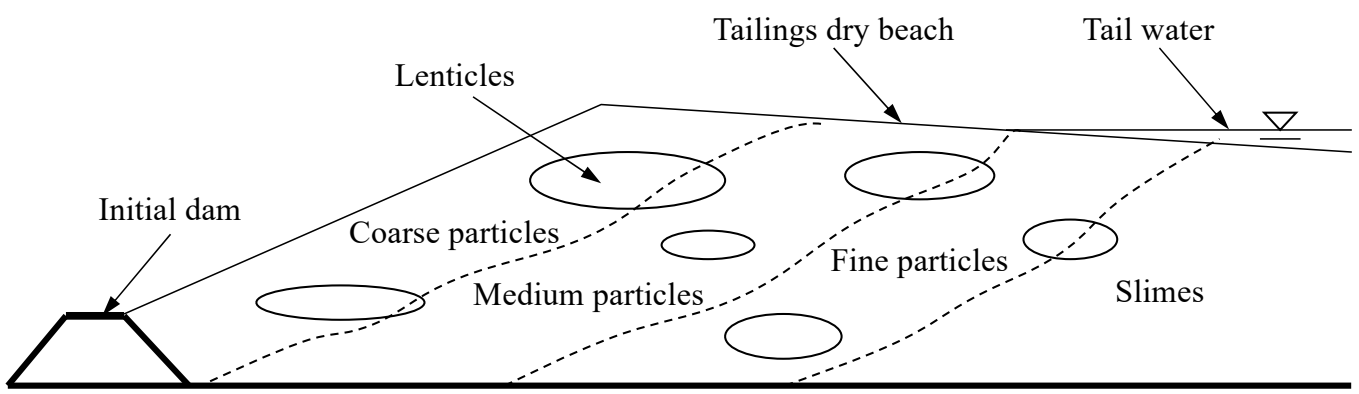

(b) Typical cross-sectional of tailings dam.

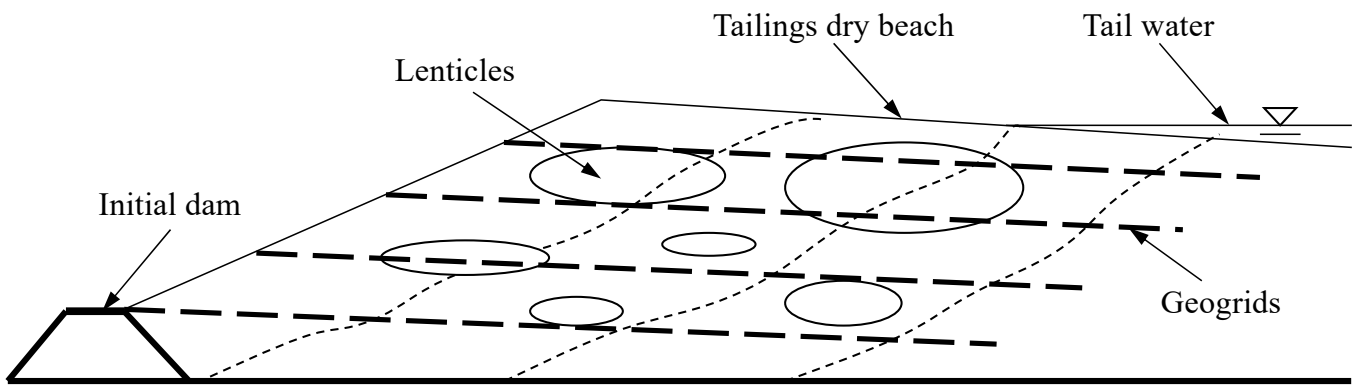

(c) Typical cross-sectional of reinforced tailings dam.

Figure 1. Cross-section of tailings dam constructed by the upstream method. (a) Ideal cross-sectional of tailings dam, (b) Typical cross-sectional of tailings dam, (c) Typical cross-sectional of reinforced tailings dam.

\section{Materials and Scheme}

\subsection{Test Materials and Sample Preparation}

The test materials were taken from a tailings reservoir in Yunnan Province, China. Before the test, the tailings were divided into tailings medium sand, tailings fine sand, tailings silty sand and tailings silt, in which tailings fine sand and tailings silt were used as test soils. The physical and mechanical parameters of the test soil were obtained by laboratory soil test, as shown in Table 1. It is well known that glass is a hard and fragile brittle material, but after that it is drawn into wire, glass fibers will have strong tensile strength and low elongation. If the glass fiber is made into a network structure, as shown in Figure 2, the strength of the glass fiber will be greater and the elongation will be lower $[27,28]$. Therefore, the reticular glass fiber is used as the reinforced material, and its performance parameters are shown in Table 2. The reinforced material is made into a circular material with a diameter of $39.1 \mathrm{~mm}$ and a height of $80 \mathrm{~mm}$, as shown in Figure 3 . In this paper, the reticular glass fiber is simply referred to as fiber. 
Table 1. Physical parameters of the experimental materials.

\begin{tabular}{|c|c|c|c|c|c|c|}
\hline Material & $\begin{array}{l}\text { Dry Density } \\
\rho /\left(\mathrm{g} \cdot \mathrm{cm}^{-3}\right)\end{array}$ & Cohesion $\mathrm{c} / \mathrm{kPa}$ & $\begin{array}{c}\text { Internal Friction } \\
\text { Angle } \varphi / /^{\circ}\end{array}$ & $\begin{array}{c}\text { Permeability } \\
\text { Coefficient } \\
\mathrm{K} /(\mathrm{cm} / \mathrm{s})\end{array}$ & $\begin{array}{l}\text { Compression } \\
\text { Coefficient } \\
\mathbf{a}_{1-2} / \mathbf{k P a}^{-1}\end{array}$ & $\begin{array}{l}\text { Effective Particle } \\
\text { Size } d_{10} / \mathrm{mm}\end{array}$ \\
\hline Tailings fine sand & 1.93 & 10.16 & 32.68 & $1.32 \times 10^{-3}$ & $1.73 \times 10^{-4}$ & $6.5 \times 10^{-3}$ \\
\hline Tailings silt & 1.82 & 13.23 & 31.11 & $1.26 \times 10^{-4}$ & $2.10 \times 10^{-4}$ & $9 \times 10^{-3}$ \\
\hline
\end{tabular}

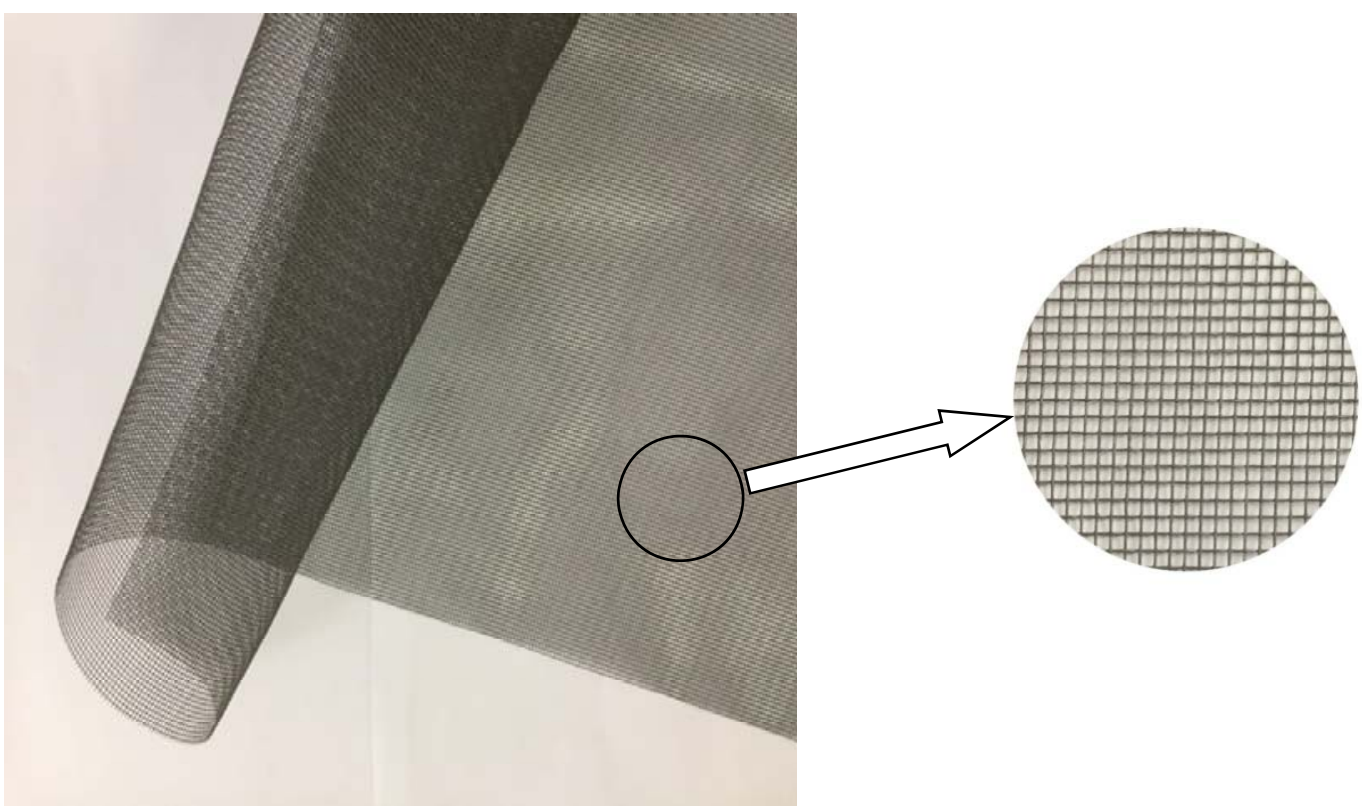

Figure 2. Reticular glass fiber.

Table 2. Strength indexes of unidirectional glass fiber

\begin{tabular}{ccccc}
\hline & Parameters & Ultimate Tensile & \multicolumn{2}{c}{ Tensile Strength at Different Strains (\%)/(KN/m) } \\
\cline { 4 - 5 } Material & & Strength/(KN/m) & 2 & 5 \\
\hline \multicolumn{2}{c}{ Fiber } & 40 & 15 & 27 \\
\hline
\end{tabular}
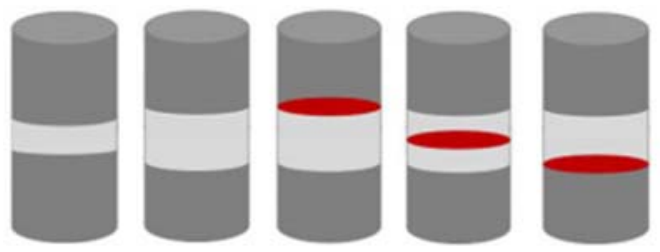

Tailings fine sand
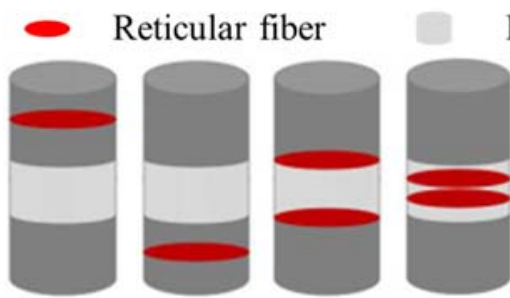

Lenticle

Figure 3. The samples.

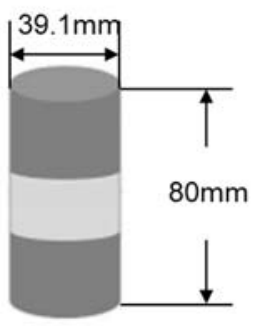

Triaxial compression tests have obtained a series of evaluations of the mechanical properties of poorly graded sand with different orientations under the action of small mesh 
inclusion with different concentrations and the aspect ratio, and analyzed the influence of micro mesh on the strength and stiffness of sandy soil [29]. Therefore, this article uses the same test method for research.

\subsection{Experiment Scheme and Process}

The test scheme consists of 10 groups, as shown in Table 3. It reflects the change in the thickness of the lenticle $d$, the number of reinforcement $n$ and the reinforcement position. The interface refers to the contact surface between the tailings fine sand and the lenticle, because the lenticle is placed in the middle of the sample, the interface is divided into an upper interface and a lower interface. The test method is the consolidated undrained shear test with confining pressure of $100 \mathrm{kPa}, 200 \mathrm{kPa}$ and $300 \mathrm{kPa}$, and a shear rate of 0.4 $\mathrm{mm} / \mathrm{min}$. In order to reduce the test error, each sample was tested three times under three confining pressures, and the average value was calculated as the analytical value. A total of 90 tests were carried out to evaluate the mechanical properties of the tailings sand with lenticle reinforced by reticular fibers.

Table 3. The experiment scheme.

\begin{tabular}{|c|c|c|c|c|c|c|c|c|c|c|}
\hline Condition & 1 & 2 & 3 & 4 & 5 & 6 & 7 & 8 & 9 & 10 \\
\hline $\begin{array}{c}\text { Lenticle } \\
\text { thickness } \\
d / \mathrm{cm}\end{array}$ & 1 & 2 & 2 & 2 & 2 & 2 & 2 & 2 & 2 & 2 \\
\hline $\begin{array}{c}\text { Fiber quantity } \\
n / \text { layer }\end{array}$ & 0 & 0 & 1 & 1 & 1 & 1 & 1 & 2 & 2 & 2 \\
\hline $\begin{array}{l}\text { Reinforcement } \\
\text { position }\end{array}$ & / & / & $\begin{array}{l}\text { At the } \\
\text { upper } \\
\text { interface }\end{array}$ & $\begin{array}{l}\text { At the } \\
\text { lower } \\
\text { interface }\end{array}$ & $\begin{array}{c}\text { Inside } \\
\text { the } \\
\text { lenticle }\end{array}$ & $\begin{array}{l}\text { Inside } \\
\text { the } \\
\text { upper } \\
\text { tailings } \\
\text { fine sand }\end{array}$ & $\begin{array}{l}\text { Inside } \\
\text { the } \\
\text { lower } \\
\text { tailings } \\
\text { fine sand }\end{array}$ & $\begin{array}{c}\text { At the } \\
\text { interface }\end{array}$ & $\begin{array}{l}\text { Inside } \\
\text { the } \\
\text { lenticle }\end{array}$ & $\begin{array}{l}\text { Inside } \\
\text { the } \\
\text { tailings } \\
\text { fine sand }\end{array}$ \\
\hline
\end{tabular}

Test procedure: Install the sample in the pressure chamber, then open the drain valve to fully drain the sample and consolidate under the confining pressure. When the consolidation is completed (the computer default consolidation degree is 0.95 ), we close the drain valve, open the pore water pressure valve, and apply the axial stress to test. The test is terminated when the sample is sheared to about $10 \%-15 \%(\varepsilon 1)$ of the axial strain, which was consistent with the deformation required to develop post-peak softening behavior in the unreinforced sand. By testing the 10 sets of experiments shown in Table 3, the strength parameters, the peak pore pressure, the shear peak, the secant stiffness corresponding to $0.3 \%$ axial strain and the axial strain at the shear peak were obtained. Additionally, the effects of the number of fibers and the position of reinforcement on the mechanical properties of tailings with lenticle were analyzed.

\section{Test Results}

\subsection{Variation of Shear Strength and Peak Pore Pressure}

Table 4 shows the shear strength parameters and the peak pore pressure of different specimens. It can be seen from the table that:

1. The cohesion of the sample containing the lenticle is smaller than the cohesion of the tailings fine sand. This cohesion is almost half of the cohesion of the tailings silt [30]. The internal friction angle of the sample containing the lenticle is larger than the internal friction angle of the tailings silt sample, but smaller than the internal friction angle of the tailings fine sand sample.

2. The cohesion and internal friction angle of the sample containing the lenticle are compared with the tailings fine sand sample, in which the cohesion changes by $3.2 \mathrm{kPa}$ $(d=2 \mathrm{~cm})$ and the internal friction angle changes by $1.24^{\circ}(d=2 \mathrm{~cm})$, indicating that the lenticle had a greater influence on the cohesion than the internal friction angle. 
3. No matter where the fibers are located, the cohesion of the specimens increase with the increase of fiber layers (within a certain range) [31], indicating that, in a certain range, the influence of the reinforced density on the cohesion of the specimens is greater than the reinforced position.

4. The improving effect of fibers on cohesion varies with the reinforced position. The overall performance is as follows: at the interface $>$ inside the tailings fine sand $>$ inside the lenticle.

5. The difference of the shear strength parameters of the sample is small when the fiber $(n=1)$ is placed at the upper interface and the lower interface, but that is significantly larger than the fibers placed in the lenticle, the upper tailings fine sand and the lower tailings fine sand. It is indicated that when the fiber $(n=1)$ is placed at the interface, the improvement on the shear strength is the best. The difference in the shear strength parameters of the sample is small when the fibers $(n=2)$ are placed in the lenticle and the tailings fine sand, both of which are less than the effect of the fibers $(n=2)$, are placed at the interface on the mechanical properties of the sample.

6. When the confining pressure $\sigma_{3}<300 \mathrm{kPa}$, the change of the peak pore pressure of the sample will not exceed $10 \mathrm{kPa}$, of which the change is not obvious, and when the confining pressure $\sigma_{3}=300 \mathrm{kPa}$, the variation of the peak pore pressure will be more obvious (minimum $9 \mathrm{kPa}$, maximum $38 \mathrm{kPa}$ ), indicating that the influence of the fiber number $n$ and the position of the reinforcement on the peak pore pressure of the sample will only become prominent under the larger confining pressure.

7. When the lenticle thickness is $d=0 \mathrm{~cm}, 1 \mathrm{~cm}$, and $2 \mathrm{~cm}$, the peak pore pressure of the sample under the confining pressure of $100 \mathrm{kPa}$ were $14 \mathrm{kPa}, 18 \mathrm{kPa}$, and $25 \mathrm{kPa}$, respectively, indicating that the lenticle increased the peak pore pressure of the sample; The thickness of the lenticle is $d=2 \mathrm{~cm}$, and when the fibers are placed in the lenticle, the peak pore pressure of the samples with the number of fibers $n=0,1$, two under the confining pressure of $100 \mathrm{kPa}$ are, respectively $25 \mathrm{kPa}, 22 \mathrm{kPa}$, and $17 \mathrm{kPa}$, which indicates that the addition of fibers reduce the peak pore pressure of the sample, and the decreased degree increased with the increase of fibers.

Table 4. The shear strength parameters and peak pore pressure of different samples.

\begin{tabular}{|c|c|c|c|c|c|c|c|c|c|c|c|c|c|}
\hline \multirow[b]{2}{*}{ Results } & Condition & $\begin{array}{l}\text { Tailings } \\
\text { Fine Sand }\end{array}$ & $\begin{array}{l}\text { Tailings } \\
\text { Silt }\end{array}$ & $\begin{array}{l}d=1, \\
n=0\end{array}$ & $\begin{array}{l}d=2, \\
n=0\end{array}$ & $\begin{array}{l}d=2, \\
n=1\end{array}$ & $\begin{array}{l}d=2, \\
n=1\end{array}$ & $\begin{array}{l}d=2, \\
n=1\end{array}$ & $\begin{array}{l}d=2, \\
n=1\end{array}$ & $\begin{array}{l}d=2, \\
n=1\end{array}$ & $\begin{array}{l}d=2 \\
n=2\end{array}$ & $\begin{array}{l}d=2, \\
n=2\end{array}$ & $\begin{array}{l}d=2 \\
n=2\end{array}$ \\
\hline & & 1 & 1 & 1 & 1 & $\begin{array}{l}\text { Inside the } \\
\text { Lenticle }\end{array}$ & $\begin{array}{l}\text { At the } \\
\text { Upper } \\
\text { Interface }\end{array}$ & $\begin{array}{l}\text { At the } \\
\text { Lower } \\
\text { Interface }\end{array}$ & $\begin{array}{l}\text { Inside the } \\
\text { Upper } \\
\text { Tailings } \\
\text { Fine Sand }\end{array}$ & $\begin{array}{l}\text { Inside the } \\
\text { Lower } \\
\text { Tailings } \\
\text { Fine Sand }\end{array}$ & $\begin{array}{l}\text { Inside the } \\
\text { Lenticle }\end{array}$ & $\begin{array}{l}\text { At the } \\
\text { Interface }\end{array}$ & $\begin{array}{l}\text { Inside the } \\
\text { Tailings } \\
\text { Fine Sand }\end{array}$ \\
\hline \multicolumn{2}{|c|}{$\begin{array}{c}\text { Cohesion } \\
\mathrm{c} / \mathrm{kPa}\end{array}$} & 10.16 & 13.23 & 6.56 & 6.96 & 20.36 & 22.36 & 22.13 & 20.86 & 20.65 & 46.68 & 48.16 & 47.13 \\
\hline \multirow{4}{*}{$\begin{array}{l}\text { Internal frict } \\
\text { Peak pore } \\
\text { pressure } \\
\mathrm{u} / \mathrm{kPa}\end{array}$} & ngle $\varphi /{ }^{\circ}$ & 32.68 & 31.11 & 32.29 & 31.44 & 31.60 & 31.95 & 31.87 & 31.69 & 31.64 & 32.15 & 32.51 & 32.28 \\
\hline & $100 \mathrm{kPa}$ & 14 & 28 & 18 & 25 & 22 & 20 & 20 & 21 & 21 & 17 & 20 & 18 \\
\hline & $200 \mathrm{kPa}$ & 30 & 56 & 36 & 40 & 37 & 33 & 34 & 34 & 35 & 30 & 33 & 32 \\
\hline & $300 \mathrm{kPa}$ & 40 & 90 & 68 & 79 & 70 & 50 & 52 & 55 & 64 & 41 & 46 & 43 \\
\hline
\end{tabular}

\subsection{Stress-Strain Curves of Reinforced Soil}

Under the same confining pressure condition, when $n=1$, the stress-strain curves of the fibers-reinforced soil at five kinds of reinforcement positions are shown in Figure 4; when $n=2$, the stress-strain curves of the fibers-reinforced soil at three kinds of reinforcement positions are shown in Figure 5. Under the same position of the reinforcement, when $n=1$, the stress-strain curves of the fibers-reinforced soil under different confining pressures are shown in Figure 6; when $n=2$, the stress-strain curves of the fibers reinforced soil under different confining pressures are shown in Figure 7. 


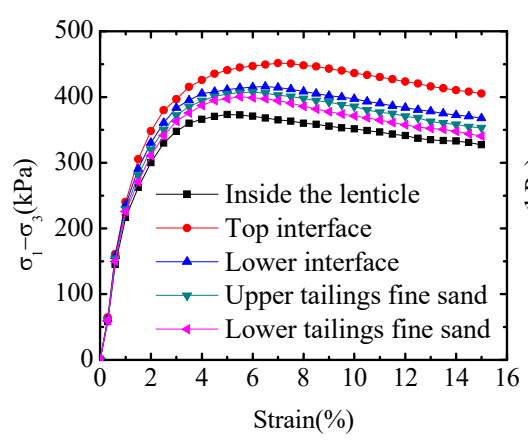

(a) Confining pressure $\sigma_{3}=100 \mathrm{kPa}$

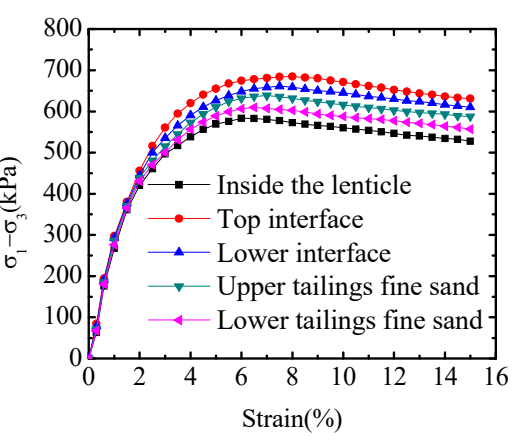

(b) Confining pressure $\sigma_{3}=200 \mathrm{kPa}$

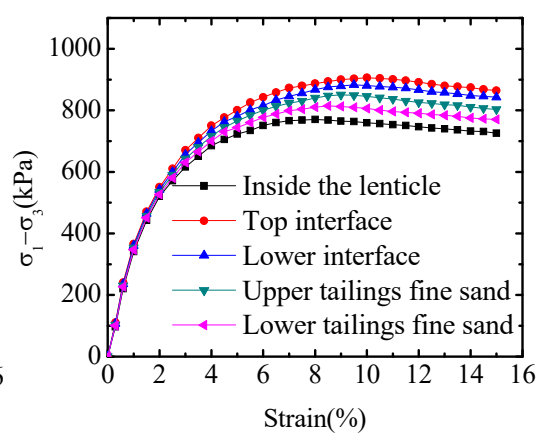

(c) Confining pressure $\sigma_{3}=300 \mathrm{kPa}$

Figure 4. Deviatoric stress-strain curves of reinforced soil in different reinforcement positions, $n=1$. (a) Confining pressure $\sigma 3=100 \mathrm{kPa},(\mathbf{b})$ Confining pressure $\sigma 3=200 \mathrm{kPa},(\mathbf{c})$ Confining pressure $\sigma 3=300 \mathrm{kPa}$.

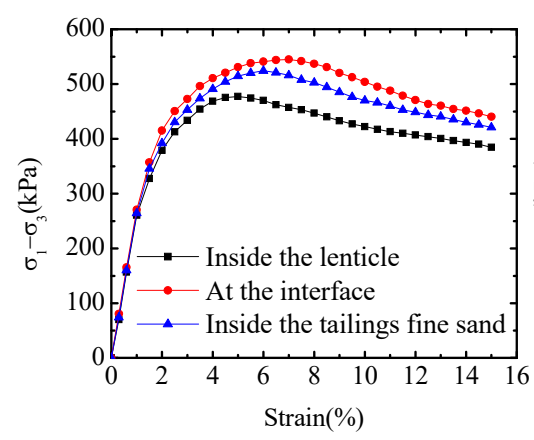

(a) Confining pressure $\sigma_{3}=100 \mathrm{kPa}$

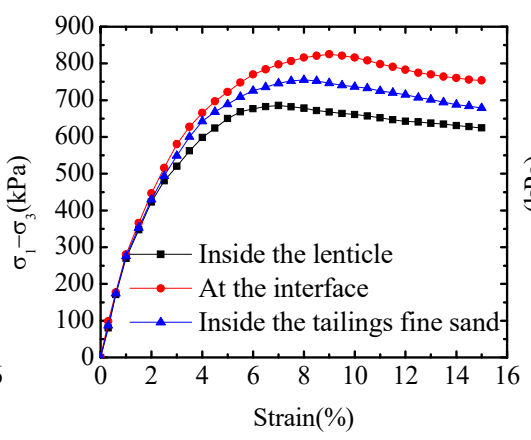

(b) Confining pressure $\sigma_{3}=200 \mathrm{kPa}$

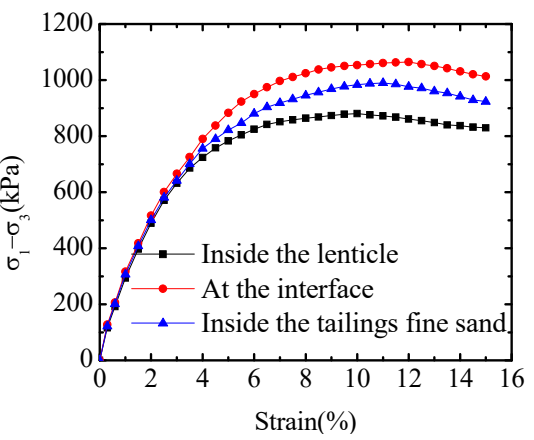

(c) Confining pressure $\sigma_{3}=300 \mathrm{kPa}$

Figure 5. Deviatoric stress-strain curves of reinforced soil in different reinforcement positions, $n=2$. (a) Confining pressure $\sigma 3=100 \mathrm{kPa}$, (b) Confining pressure $\sigma 3=200 \mathrm{kPa},(\mathbf{c})$ Confining pressure $\sigma 3=300 \mathrm{kPa}$.

It can be seen from Figures 4 and 5 that (1) under the condition of small axial strain, the deviatoric stress-strain curves of the reinforced soil were relatively close, and the smaller the stress, the higher the degree of coincidence. As the axial strain increases, the spacing between the curves increases gradually, and the smaller the stress, the smaller the strain corresponding to spacing mutation. Under the $300 \mathrm{kPa}$ confining pressure, after the axial strain reaches $6 \%$, the curve spacing was more obvious. (2) Compared to Figures $4 \mathrm{a}$ and $5 \mathrm{a}$, it can be seen that the peak deviational stress of reinforced soil increases with the increase in the number of fibers under the same confining pressure, which indicates that the fiber can increase the peak deviational stress of specimens, and the specimens with more fibers can be deformed or destroyed under larger loads than those with less fibers.

It can be seen from Figures 6 and 7: (1) Under the action of $100 \mathrm{kPa}$ confining pressure, no matter where the fiber was laid, the stress-strain curve of reinforced soil has a peak value, which is shown as strain softening type. After reaching the peak, the curve shows a downward trend and gradually becomes gentle, showing that the strain hardens gradually [32,33]. (2) It can be seen from Figure 7a that the peak deviational stress of the reinforced soil were about $470 \mathrm{kPa}\left(\sigma_{3}=100 \mathrm{kPa}\right), 680 \mathrm{kPa}\left(\sigma_{3}=200 \mathrm{kPa}\right)$, and $890 \mathrm{kPa}\left(\sigma_{3}=\right.$ $300 \mathrm{kPa}$ ), indicating that the peak deviational stress of reinforced soil increases with the increase of confining pressure under the condition that the number of fibers and the position of reinforcement remain constant. (3) The axial strain of the reinforced soil reaching the shear peak increases with the increase in the confining pressure, which indicates that the sample needs to undergo more deformation to break under the larger confining pressure. (4) Compared with Figure 7a-c, it can be seen that the peak deviational stress of reinforced soil were about $890 \mathrm{kPa}$ (inside the lenticle, $\sigma_{3}=300 \mathrm{kPa}$ ), $1080 \mathrm{kPa}$ (at the interface, $\sigma_{3}=$ $300 \mathrm{kPa}$ ), and $990 \mathrm{kPa}$ (inside the tailings fine sand, $\sigma_{3}=300 \mathrm{kPa}$ ). The results show that 
the improvement effect of the fibers $(n=2)$ at the interface is the best and the effect in the lenticle is the worst.

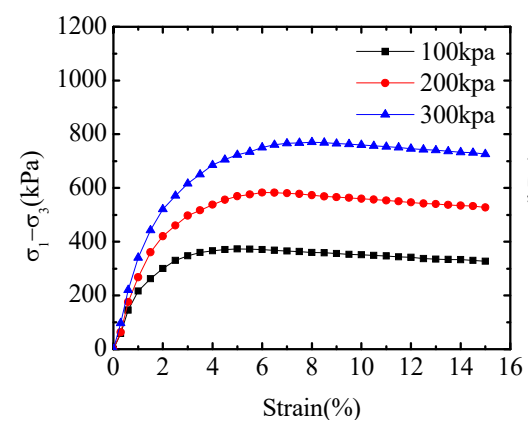

(a) Inside the lenticle

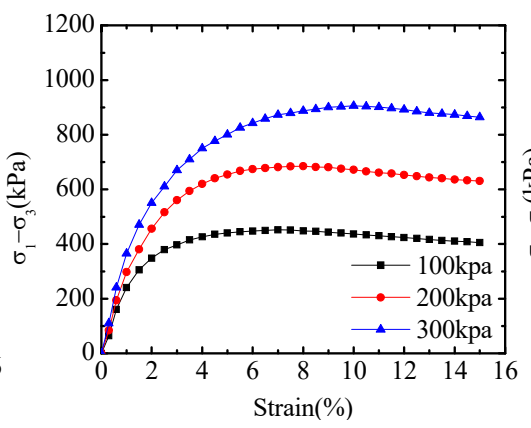

(b) At the upper interface

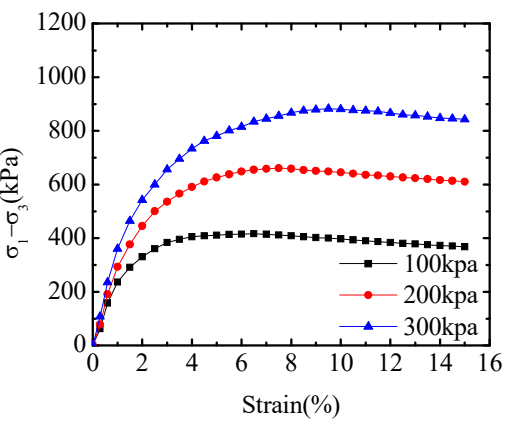

(c) At the lower interface

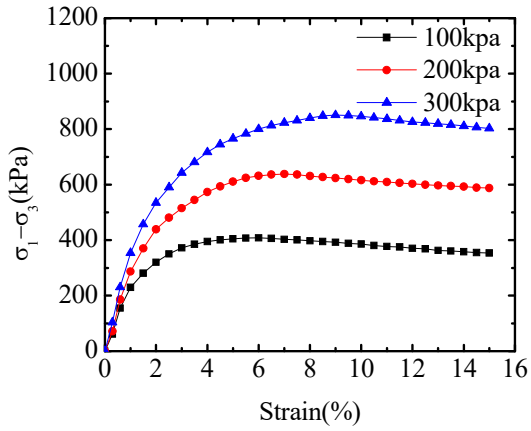

(d) Inside the upper tailings fine sand

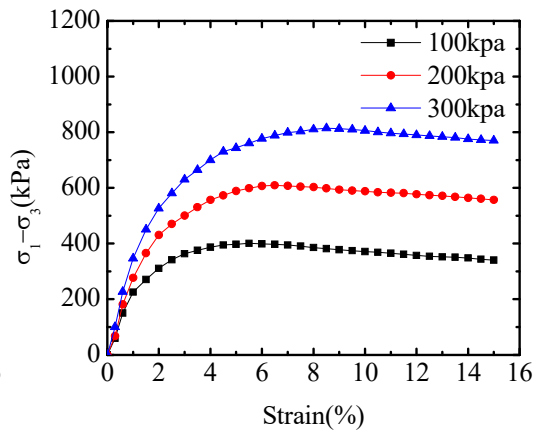

(e) Inside the lower tailings fine sand

Figure 6. Deviatoric stress-strain curves of reinforced soil under different confining pressure, $n=1$. (a) Inside the lenticle, (b) At the upper interface, (c) At the lower interface, (d) Inside the upper tailings fine sand, (e) Inside the lower tailings fine sand.

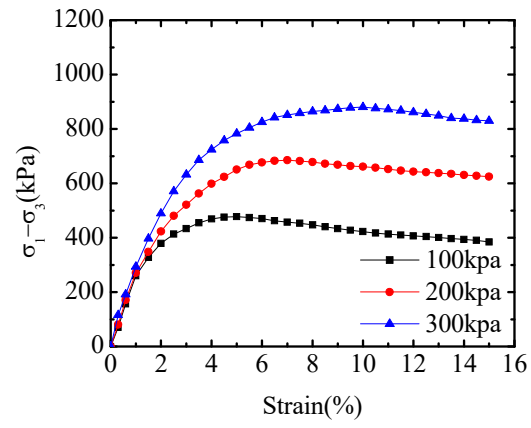

(a) Inside the lenticle

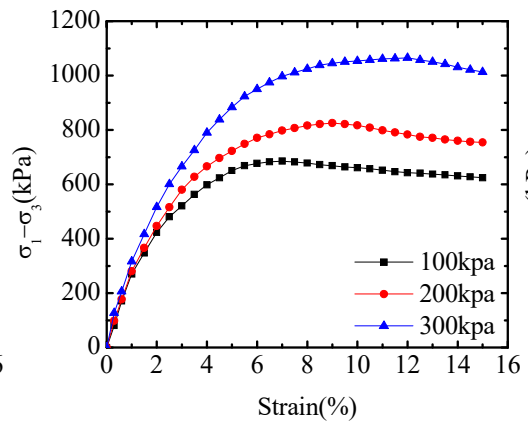

(b) At the interface

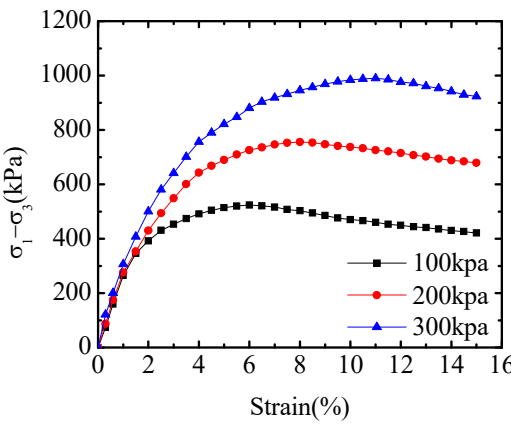

(c) Inside the tailings fine sand

Figure 7. Deviatoric stress-strain curves of reinforced soil under different confining pressure, $n=2$. (a) Inside the lenticle, (b) At the interface, (c) Inside the tailings fine sand.

\subsection{Secant Stiffness}

The secant stiffness is the ratio of the total stress to the total elastic strain at any point on the deviatoric stress-strain curve, so the material has different secant stiffness under different axial strain conditions. In this triaxial test, the secant stiffness of the reinforced tailings (including the lenticle) is evaluated based on the secant stiffness of $0.3 \%$ axial strain [29] (as shown in Figure 8). The calculation equation of the secant stiffness is as follows:

$$
E_{0.3}=\frac{\sigma_{0.3 \%}}{0.3 \%}
$$




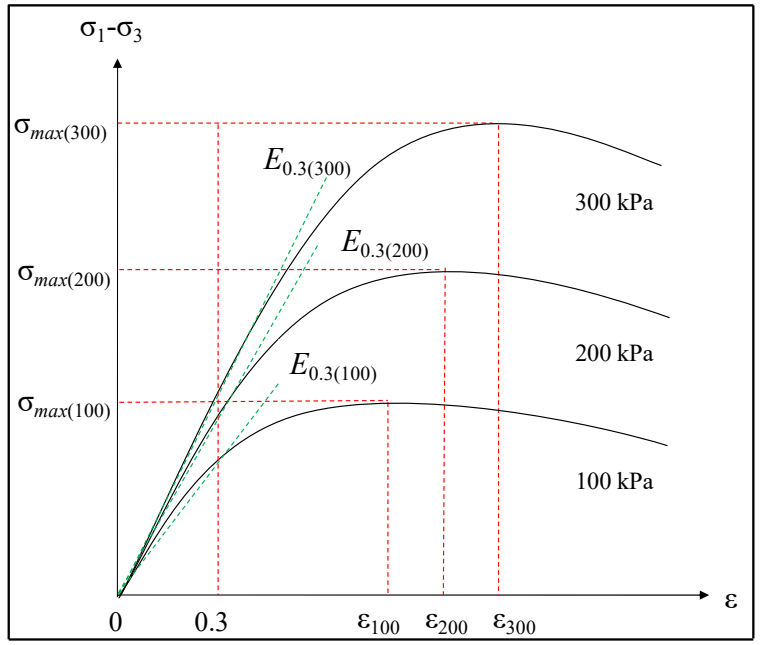

Figure 8. Secant stiffness calculation model.

Where $\sigma_{0.3 \%}$ is the deviatoric stress at the $0.3 \%$ axial strain of the sample, and the secant stiffness $E_{0.3}$ of each sample is calculated according to this equation, as shown in Table 5.

Table 5. The stiffness parameter of the tailings sand.

\begin{tabular}{|c|c|c|c|c|c|c|c|c|c|c|c|c|}
\hline & Condition & $\begin{array}{l}\text { Tailings } \\
\text { Fine } \\
\text { Sand }\end{array}$ & $\begin{array}{l}d=1 \\
n=0\end{array}$ & $\begin{array}{l}d=2 \\
n=0\end{array}$ & $\begin{array}{l}d=2 \\
n=1\end{array}$ & $\begin{array}{l}d=2 \\
n=1\end{array}$ & $\begin{array}{l}d=2 \\
n=1\end{array}$ & $\begin{array}{l}d=2 \\
n=1\end{array}$ & $\begin{array}{l}d=2 \\
n=1\end{array}$ & $\begin{array}{l}d=2 \\
n=2\end{array}$ & $\begin{array}{l}d=2 \\
n=2\end{array}$ & $\begin{array}{l}d=2 \\
n=2\end{array}$ \\
\hline Stiffness & & I & I & I & $\begin{array}{c}\text { Inside } \\
\text { the } \\
\text { Lenticle }\end{array}$ & $\begin{array}{l}\text { At the } \\
\text { Upper } \\
\text { Interface }\end{array}$ & $\begin{array}{l}\text { At the } \\
\text { Lower } \\
\text { Interface }\end{array}$ & $\begin{array}{l}\text { Inside } \\
\text { the } \\
\text { Upper } \\
\text { Tailings } \\
\text { Fine } \\
\text { Sand }\end{array}$ & $\begin{array}{l}\text { Inside } \\
\text { the } \\
\text { Lower } \\
\text { Tailings } \\
\text { Fine } \\
\text { Sand }\end{array}$ & $\begin{array}{c}\text { Inside } \\
\text { the } \\
\text { Lenticle }\end{array}$ & $\begin{array}{l}\text { At the } \\
\text { Interface }\end{array}$ & $\begin{array}{c}\text { Inside } \\
\text { the } \\
\text { Tailings } \\
\text { Fine } \\
\text { Sand }\end{array}$ \\
\hline Secant & $100 \mathrm{kPa}$ & 19.02 & 17.73 & 18.31 & 19.40 & 21.46 & 20.68 & 20.32 & 19.93 & 23.43 & 26.80 & 24.70 \\
\hline stiffness & $200 \mathrm{kPa}$ & 20.59 & 18.27 & 19.45 & 21.08 & 25.09 & 24.83 & 23.89 & 22.46 & 26.79 & 32.76 & 29.03 \\
\hline $\mathrm{E}_{50} / \mathrm{MPa}$ & $300 \mathrm{kPa}$ & 31.32 & 27.46 & 29.33 & 32.26 & 36.78 & 35.75 & 34.50 & 33.46 & 38.42 & 42.44 & 40.46 \\
\hline
\end{tabular}

It can be seen from the table that: (1) The existence of lenticle reduces the stiffness of the tailings fine sand, and the stiffness of the specimen decreases with the increase of the thickness of the lenticle. However, the addition of fibers increases the stiffness of the tailings sample containing the lenticle under triaxial pressure. Under the same reinforced condition, the secant stiffness increases with the increase in confining pressure. (2) Under the same confining pressure, the stiffness of the sample is not much different when the fiber $(n=1)$ is placed in the lenticle, in the upper tailings fine sand and the lower tailings fine sand. When $n=1$, the secant stiffness of the specimen has the following relationship: at the upper interface $>$ at the lower interface $>$ inside the upper tail fine sand $>$ inside the lower tail fine sand $>$ inside the lenticle. At the same confining pressure $(n=2)$, the stiffness of the specimen is the largest at the interface, the second inside the tailings fine sand, and the smallest inside the lenticle.

\section{Discussion}

\subsection{Reinforcement Mechanism}

The strength and stiffness of the tailings containing lenticle are improved by adding the fibers into the tailings, especially under the condition of two layers of fiber reinforcement. The strength of sand will be increased after reinforcement, due to the interaction of the force between fibers and sand, including the friction between fibers and soil, and the passive impedance effect of transverse ribs and longitudinal ribs of fibers due to soil action.

Friction between fibers and soil can be explained by the friction reinforcement principle. As stated in document [34], if $d F>d T$ ( $d F$ is the total friction force between sand 
particles and reinforced material; $d T$ is the tensile force of the horizontal thrust of the soil on the reinforced material), then the lateral stress of sand soil can be overcome by the friction force between the particles and reinforced material, so there is no dislocation between particles and reinforced material, and the micro-element body of the reinforced sand remains stable.

However, the friction force between sand particles can also overcome the horizontal thrust of sand, the friction force is much smaller than that between particles and reinforced material. Therefore, when sand is subjected to higher horizontal thrust, only the friction force between soil particles cannot overcome this horizontal thrust, and then the friction force between reinforced material and particles will play a good role. Therefore, the reinforced soil has higher strength than the unreinforced soil.

When the soil particles are in contact with the grids, it will be subjected to the passive impedance of transverse ribs and longitudinal ribs of the fibers, thus constraining the lateral displacement of the soil particles. The impedance action of ribs is defined as the "interlocking effect" of grids, and its principle is shown in Figure 9.

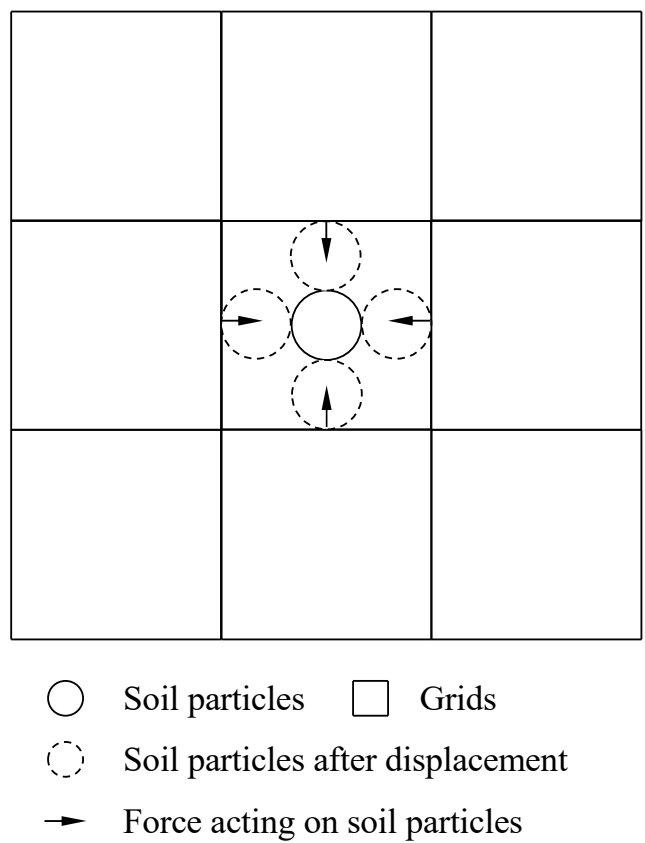

Figure 9. Schematic diagram of the grid interlocking effect.

The reticular fibers only depend on the friction of the rib-soil interface at the initial strain. As the displacement increases, the passive impedance of the mesh ribs gradually plays a dominant role and bears most of the load. When the soil particles overcome the friction force to extrude the transverse and longitudinal ribs of the fibers, the reticular fibers mainly rely on the passive impedance force of the ribs to restrict the lateral deformation of the soil. At the same time, the soil transfers the stress to the grids by interlocking action with the grids. The grids use its unique structure to play the role of stress diffusion, as shown in Figure 10. 


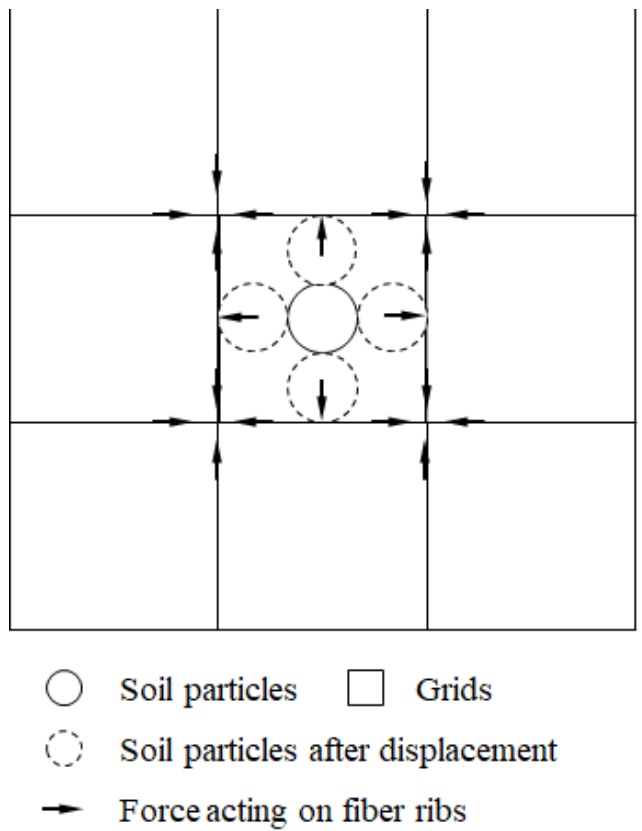

Figure 10. Schematic diagram of the force diffusion.

\subsection{Strength and Stiffness of Reinforced Soil}

Since the mechanical model of layered reinforced soil is quite complex, only the strength and stiffness of non-layered soil reinforced with reticular fiber are discussed here. The reinforcing effect of fibers on soil is mainly reflected in the restraint effect of strong tensile properties of fibers' on lateral displacement of soil particles. The increase in strength caused by the constraint of the contact surface is interpreted as the homo-cohesion generated by the constraint of contact surface [35]. Additionally, the shear strength of reinforced soil with fibers can be expressed as:

$$
\tau_{r}=\tau+c_{r}
$$

where $\tau_{r}$ is the shear strength $(\mathrm{kPa})$ of the fibers-reinforced soil, $\tau$ is the shear strength $(\mathrm{kPa})$ of the plain soil, and $c_{r}$ is the homo-cohesion $(\mathrm{kPa})$ of the fiber acting on the soil particles.

At the same time, the homo-cohesion of the fiber acting on the soil particles can be expressed by the following Equation:

$$
c_{r}=\frac{T}{a}
$$

where $T$ is the tensile strength $(n)$ of the fiber and $a$ is the soil area $\left(\mathrm{m}^{2}\right)$ in contact with the fiber.

Therefore, the shear strength of reinforced soil with fiber is as follows:

$$
\tau_{r}=\tau+\frac{T}{a}
$$

According to Mohr-Coulomb strength theory, Equation (4) can be changed into:

$$
\tau_{r}=c+\sigma \tan \varphi+\frac{T}{a}
$$

where $c$ is the cohesion of plain soil, and $\varphi$ is the internal friction angle of the plain soil.

It can be seen that the factors affecting the shear strength of reinforced soil include the cohesion and the internal friction angle of plain soil, the tensile strength of the fiber and the soil area contacted by the fiber. The relevant parameters can be obtained by a triaxial test, direct shear test and pull-out test. 
The increase in the strength of the tailings containing the lenticle caused by the fibers can be evaluated by the ratio of the cohesion/internal friction angle of the reinforced tailings sand, $c_{(\text {reinforced })}, \varphi_{(\text {reinforced })}$, to the cohesion/internal friction angle of the unreinforced tailings, $c_{\text {(unreinforced) }}, \varphi_{\text {(unreinforced) }}$. The factor that improves the strength of tailings sand is defined as $I F$, and $I F$ includes $I F_{c}$ and $I F_{\varphi}$, and is defined as:

$$
\left.\begin{array}{rl}
I F_{c} & =\frac{c_{(\text {reinforced })}}{c_{(\text {unreinforced })}} \\
I F_{\varphi} & =\frac{\varphi_{(\text {reinforced })}}{\varphi_{(\text {unreinforced })}}
\end{array}\right\}
$$

The values of IF are shown in Table 6. It can be seen from the table that when the fiber $(n=1)$ was located in the lenticle, the strength of the fiber on the tailings sand was significantly improved, wherein the cohesion was increased by $193 \%$ and the internal friction angle was increased by $0.5 \%$. When the fibers $(n=2)$ were located at the upper (lower) interface, the improvement effect of the fibers was more obvious, wherein the cohesion was increased by $592 \%$ and the internal friction angle was increased by $3.4 \%$; it shows that, within a certain range, the greater the reinforced density of the interface between the lenticle and the tailings and the higher the fiber content, it is more beneficial to improve the strength of the tailings containing the lenticle.

Table 6. Strength improvement coefficient of tailings under different reinforcement schemes.

\begin{tabular}{|c|c|c|c|c|c|c|c|c|c|}
\hline & Condition & $\begin{array}{l}n=1 \text {, Inside } \\
\text { the Lenticle }\end{array}$ & $\begin{array}{c}n=1, \text { Upper } \\
\text { Interface }\end{array}$ & $\begin{array}{c}n=1, \text { Lower } \\
\text { Interface }\end{array}$ & $\begin{array}{c}n=1, \text { Upper } \\
\text { Tailings } \\
\text { Fine Sand }\end{array}$ & $\begin{array}{c}n=1, \text { Lower } \\
\text { Tailings } \\
\text { Fine Sand }\end{array}$ & $\begin{array}{l}n=2 \text {, Inside } \\
\text { the Lenticle }\end{array}$ & $\begin{array}{c}n=2, \text { At the } \\
\text { Interface }\end{array}$ & $\begin{array}{c}n=2, \text { Inside } \\
\text { the Tailings } \\
\text { Fine Sand }\end{array}$ \\
\hline \multicolumn{10}{|c|}{ Improvement Coefficient } \\
\hline \multirow{2}{*}{ IF } & $I F_{c}$ & 2.93 & 3.21 & 3.18 & 3.00 & 2.97 & 6.71 & 6.92 & 6.77 \\
\hline & $I F_{\varphi}$ & 1.005 & 1.016 & 1.014 & 1.008 & 1.006 & 1.023 & 1.034 & 1.027 \\
\hline & $100 \mathrm{kPa}$ & 1.06 & 1.17 & 1.13 & 1.11 & 1.09 & 1.28 & 1.46 & 1.35 \\
\hline \multirow[t]{2}{*}{$I F_{E 0 \cdot 3}$} & $200 \mathrm{kPa}$ & 1.08 & 1.29 & 1.28 & 1.23 & 1.15 & 1.38 & 1.68 & 1.49 \\
\hline & $300 \mathrm{kPa}$ & 1.10 & 1.25 & 1.22 & 1.18 & 1.14 & 1.31 & 1.45 & 1.38 \\
\hline
\end{tabular}

In triaxial tests, the secant stiffness of the specimens increases with the addition of fibers, which can be evaluated by the ratio of secant modulus of reinforced tailings,

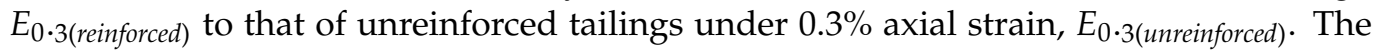
improvement factor of secant stiffness of tailings sand is defined as $I F_{E 0 \cdot 3}$, which is:

$$
I F_{E 0.3}=\frac{E_{0.3(\text { reinforced })}}{E_{0.3(\text { unreinforced })}}
$$

The values of $I F_{E 0.3}$ in the whole triaxial test are shown in Table 6. As can be seen from the table, all the tests show that the fibers can increase the secant stiffness of the sample, but the increment varies with the confining pressure, the number of reinforcement, and the position of reinforcement. The higher secant modulus were exhibited for higher reinforcement density. For example, when the fiber layer number is large for a given confining pressure $\left(n=2, \sigma_{3}=200 \mathrm{kPa}\right.$, at the interface), the secant stiffness of the specimens was increased by $68 \%$; while the secant stiffness of the specimens was increased by only $8 \%$ when the fiber layer number is small for the same confining pressure $\left(n=1, \sigma_{3}=\right.$ $200 \mathrm{kPa}$, inside the lenticle). The reason is that, when $n=2$, the dislocation trend of more soil particles is limited by the interlocking effect of grids in the fibers.

The coupling effect between fiber density and reinforcement location plays an important role in the mechanical properties of specimens. Higher reinforcement density $(n=2)$ and the reasonable reinforcement location greatly improve the comprehensive strength and stiffness of the specimen, especially at the interface between the tailings fine sand and the lenticle, where the cohesion, internal friction angle and secant stiffness of the specimens were increased by $592 \%, 3.4 \%$ and $68 \%\left(\sigma_{3}=200 \mathrm{kPa}\right)$. The reason is that there are differences in the properties of two types of soil, and it is easier to dislocate at the interface, 
where reinforcement can greatly improve the composite strength and composite stiffness of the specimens. It can also be seen from Table 6 that the fiber has the greatest improvement in the cohesion of the sample and the minimum improvement in the internal friction angle. For example, when the fiber was placed at the upper interface $\left(n=1, \sigma_{3}=200 \mathrm{kPa}\right)$, the cohesion, secant stiffness, and internal friction angle of the sample were increased by $221 \%$, $29 \%$, and $1.6 \%$, respectively, as compared to those without reinforcement.

It is found that, in a certain range, the strength and stiffness of the specimen increase with the increase of the fiber density. This only shows that the greater the reinforcement density, the better the mechanical properties of the specimen. It does not mean that the greater the reinforcement density, the better the properties of the tailings dam, because the saturation line and the mechanical properties of the tailings sand all have a great influence on the stability of the tailings dam in the actual site. If the reinforced materials are increased blindly, the strength of the tailings dam will be increased, but at the same time, the permeability of the tailings dam will be reduced, and then the height of the saturation line of the tailings dam will be raised. The saturation line is an important factor affecting the stability of tailings dam. Generally speaking, the higher the saturation line, the worse the dam's stability.

The position of the reinforcement played an important role in the reinforcement effect. In the whole test, the reinforcement effect at the interface is the best, followed by inside the tailings fine sand and the worst inside the lenticle. The reason may be that: (1) the cohesion of the soil increases with the decrease of the particle size, and the particle size of the tailings fine sand is larger than that of the lenticle, so the degree of occlusion between particles is smaller than that of the lenticle; (2) The laying of fibers increases the bite force between particles, and reduces the tendency of the particles to dislocate. Since the bite force of the lenticle particles is large, the increase of fibers has little effect on the cohesion of lenticle. On the contrary, the tailings fine sand particles have poor bite force, so the effect of fibers on the cohesion of tailings fine sand is obvious; (3) the interface is a complex of tailings fine sand and lenticle, which is non-uniformly mixed. It is more likely to dislocate at the interface between two materials, so the enhancement effect of cohesion at the interface is the best.

\subsection{Stress and Strain of Reinforced Soil}

Since the mechanical model of the layered reinforced soil is quite complex, only the stress and strain of non-layered soil reinforced with reticular fiber are discussed here. Assume that the tensile stress and strain are negative, while the compressive stress and strain are positive. It is assumed that the macroscopic stress and strain of the reinforced soil has the following relationship with the microscopic stress and strain of the fiber and plain soil:

$$
\left.\begin{array}{c}
\sigma_{i j}=\left(1-n_{1}\right) \sigma_{i j}{ }^{s}+n \sigma_{i j}{ }^{r} \\
\varepsilon_{i j}=\left(1-n_{1}\right) \varepsilon_{i j}{ }^{s}+n \varepsilon_{i j}{ }^{r}
\end{array}\right\}
$$

where $\sigma_{i j}, \varepsilon_{i j}, \sigma_{i j}{ }^{s}, \varepsilon_{i j}{ }^{s}, \sigma_{i j}{ }^{r}, \varepsilon_{i j}{ }^{r}$ are the microscopic stress and strain of reinforced soil, plain soil and fiber, respectively; $\sigma_{x}, \sigma_{x}{ }^{s}, \sigma_{x}{ }^{r}$ are the horizontal stress of reinforced soil, plain soil and fiber, respectively; $\sigma_{y}, \sigma_{y}{ }^{s}, \sigma_{y}{ }^{r}, \varepsilon_{x}, \varepsilon_{x}{ }^{s}, \varepsilon_{x}{ }^{r}$ are the axial stress and transverse strain of reinforced soil, plain soil and fiber, respectively; $\varepsilon_{y}, \varepsilon_{y}{ }^{s}$ are the axial strain of reinforced soil and plain soil, respectively; $n_{1}, e, \Delta h$ are the volume reinforcement ratio, thickness and spacing of the fibers, $e=0.001 \mathrm{~mm}$ (thickness of fibers commonly used in laboratory). 
When the soil is in the elastic stage, under the condition of plane strain, the axial and transverse strain have the following relations [36]:

$$
\left.\begin{array}{l}
\varepsilon_{x}{ }^{s}=\frac{1-v_{s}{ }^{2}}{E_{s}}\left(\sigma_{x}{ }^{s}-\frac{v_{s}}{1-v_{s}} \sigma_{y}{ }^{s}\right) \\
\varepsilon_{y}{ }^{s}=\frac{1-v_{s}^{2}}{E_{s}}\left(\sigma_{y}{ }^{s}-\frac{v_{s}}{1-v_{s}} \sigma_{x}{ }^{s}\right)
\end{array}\right\}
$$

where $v_{s}$ and $E_{s}$ are the poisson's ratio and deformation modulus of plain soil, respectively.

The relationship between the stress $\sigma_{x}^{r}$ of fiber along the length direction and the tensile force $R$ of the unit width is as follows [37]:

$$
n_{1} \sigma_{x}^{r}=-10^{3} \frac{R}{\Delta h}
$$

The relationship between the stress $\sigma_{y}{ }^{r}$ of fiber along the thickness direction and the pressure $p$ of the unit width is as follows [37]:

$$
n_{1} \sigma_{y}{ }^{r}=10^{3} \frac{p}{e}
$$

Equations (8)-(10) are substituted for (11) to obtain:

$$
\left.\begin{array}{l}
\varepsilon_{x}=\frac{1+v_{s}}{E_{s}}\left[\frac{\left(1-v_{s}\right)}{1-n_{1}} \sigma_{x}-\frac{v_{s}}{1-n_{1}} \sigma_{y}-\frac{\left(1-v_{s}\right) n_{1}}{1-n_{1}} \sigma_{x}^{r}{ }^{r}\right. \\
\varepsilon_{y}=\frac{1+v_{s}}{E_{s}}\left[\frac{\left(1-v_{s}\right)}{1-n_{1}} \sigma_{y}-\frac{v_{s}}{1-n_{1}} \sigma_{x}-\frac{\left(1-v_{s}\right) n_{1}}{1-n_{1}} \sigma_{y}^{r}\right]
\end{array}\right\}
$$

From Equation (10), it can be seen that the volume reinforcement ratio of fibers is very small, so $\left(1-n_{1}\right) \rightarrow 1$, and the strain of reinforced soil in the elastic stage can be obtained by combining Equations (12) and (13), as follows:

$$
\left.\begin{array}{l}
\varepsilon_{x}=\frac{1+v_{s}}{E_{s}}\left[\left(1-v_{s}\right) \sigma_{x}-v_{s} \sigma_{y}\right]+\frac{\left(1-v_{s}^{2}\right)}{E_{s} \Delta h} 10^{3} R \\
\varepsilon_{y}=\frac{1+v_{s}}{E_{s}}\left[\left(1-v_{s}\right) \sigma_{y}-v_{s} \sigma_{x}\right]-\frac{\left(1-v_{s}^{2}\right)}{E_{s} e} 10^{3} p
\end{array}\right\}
$$

It can be seen from Equation (15) that the strain of reinforced soil is related to tensile stress, compressive stress, fiber thickness, spacing of reinforced layers, Poisson's ratio and deformation modulus of plain soil per unit width of fiber. While the axial strain of reinforced soil is given in this paper, in fact, the compressive strain of fiber has little change, so the compressive strain of reinforced soil can be approximately equal to that of plain soil, so only the transverse strain of reinforced soil can be considered in practical calculation. In this paper, the purpose of Equation (15) is to discuss the stress and strain of reinforced soil, so it has not been verified and analyzed.

Under the condition of small strain, the test is in the stage of pore-fissure compaction, the pores among soil particles decreases gradually, and the specimen is compacted gradually. At this stage, the fiber had no obvious reinforcement effect. Therefore, the deviational stress-strain curves of the specimens were in good agreement under the condition of any reinforcement density and location, as shown in Figures 4 and 5. The greater the contact area between fiber and soil, the stronger the stability of the specimen. Thus, in a certain range, the strength of the reinforced soil increases with the increase of the reinforcement density. Therefore, the specimen with a large amount of fibers has a large bearing capacity when it is broken. For example, when the fibers were located in the lenticle for a given confining pressure $\left(\sigma_{3}=300\right.$ $\mathrm{kPa}$ ), the peak deviatoric stress of the specimen under different reinforced densities was 770 $\mathrm{kPa}(n=1$, Figure $4 \mathrm{c})$ and $861 \mathrm{kPa}(n=2$, Figure $5 \mathrm{c})$. Confining pressure restricts the lateral development of soil particles, and the original mechanical structure of soil is not easy to be destroyed. Therefore, reinforced soil needs to develop to a larger displacement under greater axial stress to cause damage, as shown in Figures 4 and 5.

As the friction resistance between soil particles and fibers limits the tendency of particle dislocation, the reinforced soil has strong shear strength. In the test, the reinforced 
specimens of the eight kinds of reinforcement positions showed the properties of plain soil in the non-reinforced area, and the properties of the reinforced soil in the reinforced area, where the whole specimen was the heterogeneous specimen. Under the action of load, the first deformation area of the fiber reinforced soil is the unreinforced area, and the force is always blocked in the reinforced area during the transfer process, which makes the non-reinforced area relatively weak. Under the condition of small confining pressure, the confining pressure has less constraint on the outward development of soil particles. At this time, the constraint of soil mainly comes from the reinforcing effect of fibers, but under the condition of large confining pressure, the confining pressure can exert obvious binding force on soil particles; at this time, the constraint of reinforced soil is provided by both the reinforcing effect of fibers and the lateral restraint of confining pressure.

\section{Conclusions}

In this study, a series of triaxial shear tests were carried out on lenticular tailings by changing the number of layers and reinforcement positions of reticular fibers. The mechanical properties of layered reinforced soil were obtained and discussed in depth. The research results can not only provide a scientific basis for the construction of reinforced tailings dam, but also provide reference for the study of layered reinforced soil. From the study presented in this paper, the following conclusions may be drawn:

- The cohesion and internal friction angle of the tailings containing the lenticle are lower than the cohesion and internal friction angle of the tailings fine sand, and the influence of the lenticle on the cohesion is much greater than the influence on the internal friction angle. Therefore, if the tailings dam contains lenticle, the stability of the tailings dam will be greatly reduced. In the construction of tailings dam, it is of great significance to simulate the construction of tailings dam and to predict the influence range of the lens, so as to strengthen the construction of tailings dam by using the mesh fiber.

- The addition of reticular fibers improves the shear strength, stiffness and deformation resistance of the specimen, but the increase amplitude varies with the reinforced density and reinforced position, and the reticular fibers also reduce the peak pore pressure of the specimen. The shear strength, stiffness and deformation resistance of the tailings sand with a layer of reticular fiber is significantly lower than that of the two layers of the reticular fiber.

- The influence degree of the reticular fiber on the shear strength parameters of the sample varies with the position of the reinforcement, which is represented by at the interface $>$ inside the tailings fine sand $>$ inside the lenticle, and the improvement effect of the reticular fibers on the cohesion is much greater than that on the internal friction angle. When the lenticle is sandwiched by two layers of reticular fibers, bounded by fibers, and the tailings with lenticle are divided into the lenticle and the tailings fine sand, the mechanical properties of the tailings containing the lenticle are the strongest, which is the most beneficial to the stability of the tailings dam. It can be seen that, in the construction of tailings dam, we need to make reasonable analysis and judgment to select the position of reinforcement, so as to get the best effect of the application of materials, so as to reduce the risk of tailings dam.

- The reinforcement effects of reticulated fibers are determined by the interaction of forces at the interface between fibers and sand. Friction, interlocking force and bond strength at the interface are the main factors controlling the benefit of fiber reinforcement, especially the friction force of fibers and interlocking force of grids. In order to strengthen the construction of tailings dam and to deal with the actual situation of complex tailings dam engineering, we can continue to study the application of various reticulation fiber materials in the future. 
Author Contributions: Conceptualization, X.J.; Methodology, C.P.; Validation, Y.C., X.L., W.W.; Supervision, X.H.; Writing-Original Draft Preparation, X.J. and C.P.; Writing-Review and Editing, X.J. and C.P. All authors have read and agreed to the published version of the manuscript.

Funding: This research is funded by the National Natural Science Foundation of China (Grants No. 51974051, 51804051, 52009131 and 51804222), the Natural Science Foundation project of Chongqing Science and Technology Commission (No. cstc2018jcyjAX0231), the Chongqing Special Postdoctoral Science Foundation (Grant No.XmT2018017), the Post-Funded Projects of Chongqing University of Science and Technology (No.ckhqzz2008005), the Key Technological Projects for Prevention and Control of Major Accidents in Safety Production (Chongqing-0009-2018AQ, Chongqing-0006-2018AQ, Chongqing-0004-2017AQ). the Self-made Equipment Foundation of Chongqing University of Science and Technology (No. ZZSB2019013), the Scientific and Technological Research Program of Chongqing Municipal Education Commission (KJZD-K201901501).

Informed Consent Statement: Informed consent was obtained from all subjects involved in the study.

Data Availability Statement: The data used to support the findings of this study are available from the corresponding author upon request.

Conflicts of Interest: The authors declare no conflict of interest.

\section{References}

1. Liu, J.; Bai, Y.; Song, Z.; Lu, Y.; Qian, W.; Kanungo, D.P. Evaluation of strength properties of sand modified with organic polymers. Polymers 2018, 10, 287. [CrossRef] [PubMed]

2. Wu, Y.; Song, W.; Zhao, W.; Tan, X. An experimental study on dynamic mechanical properties of fiber-reinforced concrete under different strain rates. Appl. Sci. 2018, 8, 1904. [CrossRef]

3. Rivera-Gómez, C.; Galán-Marín, C.; Bradley, F. Analysis of the influence of the fiber type in polymer matrix/fiber bond using natural organic polymer stabilizer. Polymers 2014, 6, 977-994. [CrossRef]

4. Liu, J.; Chen, Z.-H.; Song, Z.-Z.; Bai, Y.-X.; Qian, W.; Wei, J.-H.; Kanungo, D.P. Tensile behavior of polyurethane organic polymer and polypropylene fiber-reinforced sand. Polymers 2018, 10, 499.

5. Fang, S.-E.; Hong, H.-S.; Zhang, P.-H. Mechanical property tests and strength formulas of basalt fiber reinforced recycled aggregate concrete. Materials 2018, 11, 1851. [CrossRef]

6. Zhu, H.H.; Zhang, C.C.; Tang, C.S.; Shi, B.; Wang, B.J. Modeling the pullout behavior of short fiber inreinforced soil. Geotext. Geomembr. 2014, 42, 329-338. [CrossRef]

7. Wang, Y.; Guo, P.; Shan, S.; Yuan, H.; Yuan, B. Study on strength influence mechanism of fiber-reinforced expansive soil using jute. Geotech. Geol. Eng. 2016, 34, 1079-1088.

8. Liu, J.; Song, Z.; Lu, Y.; Wang, Q.; Kong, F.; Bu, F.; Kanungo, D.P.; Sun, S. Improvement effect of water-based organic polymeron the strength properties of fiber glass reinforced sand. Polymers 2018, 10, 836. [CrossRef]

9. Yin, G.; Wei, Z.; Wang, J.G.; Wan, L.; Shen, L. Interaction characteristics of geosynthetics with fine tailings in pullout test. Geosynth. Int. 2008, 15, 428-436.

10. Özer, A.T.; Bromwell, L.G. Stability assessment of an earth dam on silt/clay tailings foundation: A case study. Eng. Geol. 2012, 29, 89-99. [CrossRef]

11. Krekeler, M.P.S.; Morton, J.; Lepp, J.; Tselepis, C.M.; Samsonov, M.; Kearns, L.E. Mineralogical and geochemical investigation of clay-rich mine tailings from a closed phosphate mine, Bartow Florida, USA. Environ. Geol. 2008, 55, 123-147. [CrossRef]

12. Li, X.B.; Jiang, W.D.; He, H.J. Study on distributing state of lenticle in tailings fill dam. Rock Soil Mech. 2004, 25, 947-949. (In Chinese)

13. Homstrom, H.; Ohlander, B. Layers rich in Fe-and Mn-oxyhydroxides formed at the tailings-Pond water interface, a Possible trap for trace metals in flooded mine tailings. J. Geoehem. Explor. 2001, 74, 189-203. [CrossRef]

14. Parker, G.; Paola, C.; Whipple, K.X.; Mohrig, D.; Toro-Escobar, C.M.; Halverson, M.; Skoglund, T.W. Alluvial fans formed by channelized fluvial and sheet flow. J. Hydraul. Eng. 1998, 124, 996-1004. [CrossRef]

15. Stark, T.D.; Eid, H.T. Drained residual strength of cohesion soils. J. Geotech. Eng. 1994, 120, 856-871. [CrossRef]

16. Al-Shayea, N.A. The combined effect of clay and moisture content of the behavior ofremolded unsaturated soils. Eng. Geol. 2001, 62, 319-342. [CrossRef]

17. Tiwari, B.; Marui, H. A new method for the correlation of residual shear strength ofthe soil with mineralogical composition. J. Geotech. Geoenviron. 2005, 131, 1139-1150. [CrossRef]

18. Dimitrova, R.S.; Yanful, E.K. Factors affecting the shear strength of mine tailings/claymixtures with varying clay content and clay mineralogy. Eng. Geol. 2012, 125, 11-25. [CrossRef]

19. Lu, R.B.; Wang, T. Safety management technique and accident-causing analysis of dam-failure in upstream tailings pond. $J$. Yangtze River Sci. Res. Inst. 2009, S1, 112-117. (In Chinese) 
20. Yuan, W.; Bai, B.; Li, X.C.; Wang, H.B. Parameters sensitivity analysis of lenticles impacting on tailings dam safety. J. Cent. South Univ. (Sci. Technol.) 2013, 44, 1174-1183. (In Chinese)

21. Li, Z.P.; Peng, Z.B.; He, Z.M.; Yuan, W. Simplification method of lenticles and its impact on safety of tailings dam. J. Cent. South Univ. (Sci. Technol.) 2017, 48, 1326-1334. (In Chinese)

22. Yang, Y.; Wei, Z.; Cao, G.; Yang, Y.; Wang, H.; Zhuang, S.; Lu, T. A case study on utilizing geotextile tubesfor tailings dams construction in China. Geotext. Geomembr. 2019, 47, 187-192. [CrossRef]

23. Wei, Z.; Yin, G.; Li, G.; Wang, J.G.; Wan, L.; Shen, L. Reinforced terraced fields method for fine tailings disposal. Miner. Eng. 2009, 22, 1053-1059. [CrossRef]

24. Jing, X.F.; Zhou, X.; Zhao, Y.S.; Liu, K.; Chen, Y.E.; Pan, C. Study on influence of reinforcement density on overtopping failure of tailings dam. J. Saf. Sci. Technol. 2016, 12, 68-74. (In Chinese)

25. Yin, G.Z.; Wei, Z.A.; Wan, L.; Zhang, D.M. TEST Study on stability of fine grained tailings dam in geo-grid reinforcement situation. Chin. J. Rock Mech. Eng. 2005, 24, 1030-1034. (In Chinese)

26. Zhao, Y.S.; Jing, X.F.; Zhou, X.; Cai, Z.Y.; Liu, K.H. Experimental study on blocking action of bar strip on tailings dam overtopping China Saf. Sci. J. 2016, 26, 94-99. (In Chinese)

27. Fang, Y.; Chen, B.; Oderji, S.Y. Experimental research on magnesium phosphate cement mortar reinforced by glass fiber. Constr. Build. Mater. 2018, 188, 729-736. [CrossRef]

28. Giusti, R.; Zanini, F.; Lucchetta, G. Automatic glass fiber length measurement for discontinuous fiber-reinforced composites Compos. Part A Appl. Sci. Manuf. 2018, 112, 263-270. [CrossRef]

29. Leshchinsky, B.; Evans, T.M.; Vesper, J. Microgrid inclusions to increase the strength and stiffness of sand. Geotext. Geomembr. 2016, 44, 170-177. [CrossRef]

30. Zhang, Q.; Yin, G.; Wei, Z.; Fan, X.; Wang, W.; Nie, W. An experimental study of the mechanical features of layered structures in dam tailings from macroscopic and microscopic points of view. Eng. Geol. 2015, 195, 142-154. [CrossRef]

31. Tran, K.Q.; Satomi, T.; Takahashi, H. Improvement of mechanical behavior of cemented soil reinforced with waste cornsilk fibers. Constr. Build. Mater. 2018, 178, 204-210. [CrossRef]

32. Khan, M.Z.N.; Hao, Y.; Hao, H.; Shaikh, F.U.A.; Liu, K. Mechanical properties of ambient cured high-strength plain and hybrid fiber reinforced geopolymer composites from triaxial compressive tests. Constr. Build. Mater. 2018, 185, 338-353. [CrossRef]

33. Wei, L.; Chai, S.X.; Zhang, H.Y.; Shi, Q. Mechanical properties of soil reinforced with both lime and four kinds of fiber. Constr. Build. Mater. 2018, 172, 300-308. [CrossRef]

34. Bao, C.G. Study on interface behavior of geosynthetics and soil. Chin. J. Rock Mech. Eng. 2006, 25, 1735-1744. (In Chinese)

35. Bauer, C.E.; Zhao, Y.J. Effect of soil dilatancy on shear strength of reinforced composites. In Proceedings of the International Conference on Geotextiles, Vienna, Austria, 7-11 April 1986; pp. 369-372.

36. Cai, M.F.; He, M.C.; Liu, D.Y. Rock Mechanics and Engineering; Science Press: Beijing, China, 2005; pp. 184-187. (In Chinese)

37. Zhou, Z.G.; Li, Y.Z. Research on constitutive model of reinforced soil considering viscoelasticity of geogrids. Chin. J. Rock Mech. Eng. 2011, 30, 850-857. (In Chinese) 